\title{
Agricultural Innovation and Sustainable Development: A Case Study of Rice-Wheat Cropping Systems in South Asia
}

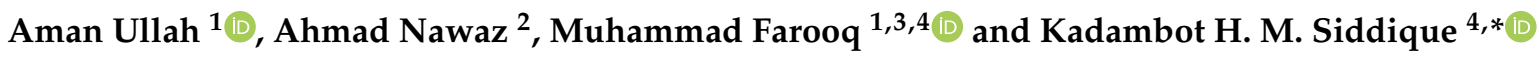 \\ 1 Department of Plant Sciences, College of Agricultural and Marine Sciences, Sultan Qaboos University, \\ Al-Khoud 123, Oman; amanullahmalik12@gmail.com (A.U.); farooqcp@squ.edu.om (M.F.) \\ 2 Centre for Agriculture and Biosciences International (CABI), Central and West Asia (CWA), Opposite 1-A, \\ Data Gunj Baksh Road, Satellite Town, Rawalpindi 46300, Pakistan; ahmadnawaz2006@gmail.com \\ 3 Department of Agronomy, University of Agriculture, Faisalabad 38040, Pakistan \\ 4 The UWA Institute of Agriculture, The University of Western Australia, Perth WA 6001, Australia \\ * Correspondence: kadambot.siddique@uwa.edu.au
}

Citation: Ullah, A.; Nawaz, A.; Farooq, M.; Siddique, K.H.M Agricultural Innovation and Sustainable Development: A Case Study of Rice-Wheat Cropping Systems in South Asia. Sustainability 2021, 13, 1965. https://doi.org/ $10.3390 /$ su13041965

Academic Editor: Roberto Mancinelli Received: 19 January 2021

Accepted: 6 February 2021

Published: 11 February 2021

Publisher's Note: MDPI stays neutral with regard to jurisdictional claims in published maps and institutional affiliations.

Copyright: (c) 2021 by the authors. Licensee MDPI, Basel, Switzerland. This article is an open access article distributed under the terms and conditions of the Creative Commons Attribution (CC BY) license (https:// creativecommons.org/licenses/by/ $4.0 /)$.

\begin{abstract}
The rice-wheat cropping system is the main food bowl in Asia, feeding billions across the globe. However, the productivity and long-term sustainability of this system are threatened by stagnant crop yields and greenhouse gas emissions from flooded rice production. The negative environmental consequences of excessive nitrogen fertilizer use are further exacerbating the situation, along with the high labor and water requirements of transplanted rice. Residue burning in rice has also severe environmental concerns. Under these circumstances, many farmers in South Asia have shifted from transplanted rice to direct-seeded rice and reported water and labor savings and reduced methane emissions. There is a need for opting the precision agriculture techniques for the sustainable management of nutrients. Allelopathic crops could be useful in the rotation for weed management, the major yield-reducing factor in direct-seeded rice. Legume incorporation might be a viable option for improving soil health. As governments in South Asia have imposed a strict ban on the burning of rice residues, the use of rice-specific harvesters might be a pragmatic option to manage rice residues with yield and premium advantage. However, the soil/climatic conditions and farmer socio-economic conditions must be considered while promoting these technologies in rice-wheat system in South Asia.
\end{abstract}

Keywords: rice-wheat cropping system; South Asia; water requirements; nitrogen; direct seeding

\section{Introduction}

Rice-wheat cropping systems (RWCS) provide staple food to $15 \%$ of the world's population [1]. The major issue for the sustainability of conventional RWCS in South Asia is soil quality degradation associated with resource scarcity [2]. Other factors include water scarcity, low soil organic matter, nutrient imbalances, labor/energy crises, complex insect and weed flora, herbicide-resistant weeds, and greenhouse gas (GHG) emissions [3]. Moreover, conventional puddled transplanted rice (PTR) cultivation has over-exploited the groundwater leading to an alarming fall in the water table in South Asia [4].

The conventional rice production systems are no longer suitable as they require large amounts of water (3000-5000 L of water to produce one $\mathrm{kg}$ of rice) [5,6]. It has been reported that 15-20 Mha of conventional rice production systems will face water shortages by 2025 [7]. In some parts of Pakistan and India, groundwater tables are declining by 1.0-3.5 $\mathrm{m}$ and $6 \mathrm{~m}$ year $^{-1}$, respectively [8].

Puddling, as practices in conventional rice-wheat system, increases the soil bulk density, which causes soil compaction [9] and affects root development in post-rice crops [3]. Nitrogen uptake in puddled rice fields declines by $12-35 \%$ in the following wheat crop due to subsoil compaction [10]. The evolution of herbicide resistant weeds and shift in weed flora (a mixture of broadleaf and grassy weeds) have further exacerbated the scenario in 
RWCS to harvest optimum crop yields [11]. Little seed canary grass (Phalaris minor Retz.) has been reported to decrease wheat yields by $10-65 \%$ with occasional crop failure [12], while smartweed (Polygonum hydropiper L.) can reduce the rice and wheat yields by $15-25 \%$ and $15-30 \%$, respectively [13]. Furthermore, the rice and wheat monocultures in RCWS have increased disease and pest problems [14] and has caused macro- and micro-nutrient deficiencies $[3,15,16]$.

In this scenario, resource conservation technologies, such as direct-seeded rice (DSR), no-till wheat, and laser-assisted land leveling, can be used to improve the sustainability of yields in RWCS [3]. Several studies reported that residue retention and no-tillage enhance the nitrogen and carbon pools in soil $[17,18]$.

This case study focuses on the problems of conventional RWCS (i.e., nutrient mining, GHG emissions, and reduced profits) and alternative options such as DSR, use of advanced rice harvesters for harvest, no-till wheat, precision agriculture, and crop rotation to improve the yields, sustainability, and the conservation of scarce natural resources.

\section{Review Methodology}

We searched more than 180 articles, including 10 review and 170 research articles, using four databases: Scopus, Web of Science, Google Scholar, and Center for Agriculture and Bioscience International (CABI). These databases are large collections of mainstream articles and are widely used for searching. The different keywords as (rice-wheat cropping system, greenhouse gases emission, direct-seeded rice, zero tillage wheat, agricultural innovation systems, profit margin in the conventional rice-wheat cropping system, crop rotation, precision agriculture, nutrient mining, agricultural sustainability, and rice-specific harvesters) were used to search the articles from these databases. To take additional information from these articles, we used references from these articles as well. The articles other than South Asia and published before the year 2000 were not included in this review.

\section{Problems in Conventional Rice-Wheat Systems}

\subsection{Greenhouse Gas Emissions}

In the Indo-Gangetic Plains (IGP), conventional RWCS is the major source of atmospheric nitrous oxide $\left(\mathrm{N}_{2} \mathrm{O}\right)$, carbon dioxide $\left(\mathrm{CO}_{2}\right)$, and methane $\left(\mathrm{CH}_{4}\right)$ emissions due to the use of intensive agricultural inputs [19], particularly the injudicious use of nitrogen fertilizers Table 1 [20,21], aerobic and anaerobic soil cycling [22], and residue burning. In northwest India, 2.5 M farmers burn 23 MMT of rice stubble each year (October to November) to prepare field for wheat crop, causing massive air pollution affecting millions of people across the IGP $[23,24]$. Annual residue burning emits GHGs, including $\mathrm{CO}_{2}$ (379 Tg), carbon monoxide (CO; $23 \mathrm{Tg}), \mathrm{CH}_{4}(0.68 \mathrm{Tg}), \mathrm{NOx}(0.96 \mathrm{Tg})$, and sulfur dioxide $\left(\mathrm{SO}_{2}\right)(0.10 \mathrm{Tg})$ [25]. The RWCS supplied with $75 \mathrm{~kg} \mathrm{~N} \mathrm{ha}^{-1}$ had mean annual emissions of $\mathrm{N}_{2} \mathrm{O}$ of $1.49 \mathrm{~kg} \mathrm{~N} \mathrm{ha}^{-1}$, or $2.97-3.04 \mathrm{~kg} \mathrm{~N} \mathrm{ha}^{-1}$ when supplied with $>150 \mathrm{~kg} \mathrm{~N} \mathrm{ha}^{-1}$ [26].

Table 1. Greenhouse gas emissions from different rice production systems.

\begin{tabular}{|c|c|c|c|}
\hline Greenhouse Gas & Quantity Emitted from DSR & Quantity Emitted from Transplanted Rice & Reference \\
\hline Methane $\left(\mathrm{CH}_{4}\right)$ & $0.49 \mathrm{mg} \mathrm{m}^{-2}$ day $^{-1}$ & $3.10 \mathrm{mg} \mathrm{m}^{-2}$ day $^{-1}$ & [27] \\
\hline Nitrous oxide $\left(\mathrm{N}_{2} \mathrm{O}\right)$ & $0.97 \mathrm{mg} \mathrm{m}^{-2}$ day $^{-1}$ & $1.03 \mathrm{mg} \mathrm{m}^{-2}$ day $^{-1}$ & \\
\hline Carbon dioxide $\left(\mathrm{CO}_{2}\right)$ & $600 \mathrm{mg} \mathrm{m}^{-2}$ day $^{-1}$ & $1800 \mathrm{mg} \mathrm{m}^{-2}$ day $^{-1}$ & \\
\hline Nitrous oxide $\left(\mathrm{N}_{2} \mathrm{O}\right)$ & $0.90 \mathrm{~kg} \mathrm{ha}^{-1}$ & $0.56 \mathrm{~kg} \mathrm{ha}^{-1}$ & [28] \\
\hline Methane $\left(\mathrm{CH}_{4}\right)$ & $23.3 \mathrm{~kg} \mathrm{ha}^{-1}$ & $32.8 \mathrm{~kg} \mathrm{ha}^{-1}$ & \\
\hline Methane $\left(\mathrm{CH}_{4}\right)$ & $18.9 \mathrm{~kg} \mathrm{ha}^{-1}$ & $28.4 \mathrm{~kg} \mathrm{ha}^{-1}$ & [29] \\
\hline Nitrous oxide $\left(\mathrm{N}_{2} \mathrm{O}\right)$ & $0.95 \mathrm{~kg} \mathrm{ha}^{-1}$ & $0.65 \mathrm{~kg} \mathrm{ha}^{-1}$ & \\
\hline Nitrous oxide $\left(\mathrm{N}_{2} \mathrm{O}\right)$ & $25 \mathrm{~kg} \mathrm{ha}^{-1}$ & $48 \mathrm{~kg} \mathrm{ha}^{-1}$ & {$[30]$} \\
\hline Nitrous oxide $\left(\mathrm{N}_{2} \mathrm{O}\right)$ & $0.12 \mathrm{~kg} \mathrm{ha}^{-1}$ & $0.11 \mathrm{~kg} \mathrm{ha}^{-1}$ & \\
\hline Methane $\left(\mathrm{CH}_{4}\right)$ & $0.2 \mathrm{~kg} \mathrm{ha}^{-1}$ & $1.1 \mathrm{~kg} \mathrm{ha}^{-1}$ & {$[31]$} \\
\hline Carbon dioxide $\left(\mathrm{CO}_{2}\right)$ & $1.2 \mathrm{~kg} \mathrm{ha}^{-1}$ & $1.3 \mathrm{~kg} \mathrm{ha}^{-1}$ & \\
\hline Nitrous oxide $\left(\mathrm{N}_{2} \mathrm{O}\right)$ & $0.6 \mathrm{~kg} \mathrm{ha}^{-1}$ & $0.4 \mathrm{~kg} \mathrm{ha}^{-1}$ & \\
\hline
\end{tabular}


Table 1. Cont.

\begin{tabular}{cccc}
\hline Greenhouse Gas & Quantity Emitted from DSR & Quantity Emitted from Transplanted Rice & Reference \\
\hline Methane $\left(\mathrm{CH}_{4}\right)$ & $6.98 \mathrm{~kg} \mathrm{ha}^{-1}$ & $18.49 \mathrm{~kg} \mathrm{ha}^{-1}$ & $3.71 \mathrm{~kg} \mathrm{ha}^{-1}$ \\
Nitrous oxide $\left(\mathrm{N}_{2} \mathrm{O}\right)$ & $3.35 \mathrm{~kg} \mathrm{ha}^{-1}$ & $60 \mathrm{~kg} \mathrm{ha}^{-1}$ & [32] \\
Methane $\left(\mathrm{CH}_{4}\right)$ & $25 \mathrm{~kg} \mathrm{ha}^{-1}$ & $315 \mathrm{~kg} \mathrm{ha}^{-1}$ & $60 \mathrm{~kg} \mathrm{ha}^{-1}$ \\
Methane $\left(\mathrm{CH}_{4}\right)$ & $220 \mathrm{~kg} \mathrm{ha}^{-1}$ & $0.10 \mathrm{~kg} \mathrm{ha}^{-1}$ & {$[33]$} \\
Methane $\left(\mathrm{CH}_{4}\right)$ & $25 \mathrm{~kg} \mathrm{ha}^{-1}$ & $271 \mathrm{~kg} \mathrm{ha}^{-1}$ & {$[35]$} \\
Nitrous oxide $\left(\mathrm{N}_{2} \mathrm{O}\right)$ & $0.12 \mathrm{~kg} \mathrm{ha}^{-1}$ & $229 \mathrm{~kg} \mathrm{ha}^{-1}$ & {$[36]$} \\
Methane $\left(\mathrm{CH}_{4}\right)$ & $129 \mathrm{~kg} \mathrm{ha}^{-1}$ & $89 \mathrm{~kg} \mathrm{ha}^{-1}$ & {$[37]$} \\
Methane $\left(\mathrm{CH}_{4}\right)$ & $269 \mathrm{~kg} \mathrm{ha}^{-1}$ & $75 \mathrm{~kg} \mathrm{ha}^{-1}$ & {$[38]$} \\
Methane $\left(\mathrm{CH}_{4}\right)$ & &
\end{tabular}

The flooding conditions in rice cause the anaerobic decomposition of organic matter, which produces methane $\left(\mathrm{CH}_{4}\right)$ in the soil [39]. Globally, rice contributes $\sim 20 \%$ of the total $\mathrm{CH}_{4}$ emissions [40]. The warming potential of $\mathrm{CH}_{4}$ is 25-30 times greater than $\mathrm{CO}_{2}$ [40,41]. In 2005, the concentration of atmospheric $\mathrm{CH}_{4}$ reached $1774 \mathrm{ppb}$ [40]. Several studies reported that PTR produces more $\mathrm{CH}_{4}$ emissions than DSR, while DSR produces more $\mathrm{N}_{2} \mathrm{O}$ than PTR [3]. In one study, DSR and PTR produced $\mathrm{N}_{2} \mathrm{O}$ emissions of $1.2 \mathrm{t} \mathrm{CO}_{2} \mathrm{eq} \mathrm{ha}^{-1}$ and $0.4 \mathrm{tCO}_{2} \mathrm{eq} \mathrm{ha}{ }^{-1}$, respectively and $\mathrm{CH}_{4}$ emissions of $0.1 \mathrm{t} \mathrm{CO}_{2} \mathrm{eq} \mathrm{ha}{ }^{-1}$ and $0.6 \mathrm{t} \mathrm{CO}_{2} \mathrm{eq}$ $\mathrm{ha}^{-1}$, respectively [42]. In conclusion, the adoption of monocultures in RWCS contributes to global GHG emissions due to intensive agricultural inputs use and residue burning.

\subsection{Nutrient Mining and Unwise Nutrient Use}

Continuous monoculture cropping has threatened the long-term sustainability and has caused macro- and micro-nutrient imbalances in RWCS [3]. In the IGP, the mining of major nutrients, including nitrogen $(\mathrm{N})$, phosphorus $(\mathrm{P})$, potassium $(\mathrm{K})$, and sulfur $(\mathrm{S})$, has created a major nutrient imbalance in RWCS. The production of $1 \mathrm{t}$ of rice/wheat depletes $20.1 / 24.5 \mathrm{~kg} \mathrm{~N}, 4.9 / 3.8 \mathrm{~kg} \mathrm{P}$, and $25.0 / 27.3 \mathrm{~kg} \mathrm{~K}$, respectively, from the soil [43], which decreases the soil productivity [44] if these nutrients are not replenished. In the IGP, the removal of crop residues removes five times more $\mathrm{K}$ than that supplied through fertilizers [45].

Among the micro-nutrients, $\mathrm{Zn}$ deficiency is more common in rice, while manganese (Mn) deficiency is more prevalent in wheat [46]. In India, $49 \%$ of soil samples were $\mathrm{Zn}$ deficient, followed by $33 \%$ deficient in B, $12 \%$ in $\mathrm{Fe}, 5 \%$ in $\mathrm{Mn}$, and $3 \%$ in $\mathrm{Cu}$ [47]. In the IGP, most rice and wheat farmers apply $\mathrm{N}$ fertilizers following blanket recommendations based on crop response data, leading to under- or over-fertilization as there is wide spatial variability in the indigenous nutrient supply capacity of soils in different agro-ecologies [26]. Diagnostic surveys of the IGP showed that farmers apply more $\mathrm{N}$ and $\mathrm{P}$ fertilizers than recommended while under/overlooking the supply of K, other secondary macronutrients, and micro-nutrients [48]. The inadequate and imbalanced use of nutrients reduces nutrient use efficiencies and profitability and increases environmental hazards [49]. In conclusion, the continuous growing of rice and wheat has resulted in the mining of major $(\mathrm{N}, \mathrm{P}, \mathrm{K}$, and $\mathrm{S})$ and trace ( $\mathrm{Zn}, \mathrm{B}$, and $\mathrm{Fe}$ ) nutrients due to over- or under-fertilization.

\subsection{Reduced Profit Margins}

The PTR has smaller profit margins than DSR due to the high labor costs Table 2 [50]. With industrialization, the migration of people to cities reduced labor availability for agricultural activities, which increased labor costs. Labor shortages delay the transplantation of rice seedlings into puddled fields [51], delaying maturation, and decrease yields [3]. 
Table 2. Profit margins in different rice production systems.

\begin{tabular}{|c|c|c|c|c|}
\hline Name of Input & Type of Soil & $\begin{array}{l}\text { Unit Cost in } \\
\text { DSR ha-1 (\$) }\end{array}$ & $\begin{array}{l}\text { Unit Cost in Transplanted } \\
\text { Rice ha } \mathbf{h a}^{-1}(\$)\end{array}$ & Reference \\
\hline Farmyard manure & Sandy loam clay & 18.40 & 13.26 & [52] \\
\hline Fertilizer & Sandy loam clay & 97.56 & 80.88 & \\
\hline $\begin{array}{l}\text { Plant protection measures (weeds, insect } \\
\text { pests and disease control) }\end{array}$ & Sandy loam clay & 54.63 & 42.09 & \\
\hline Land preparation & Sandy loam clay & 59.01 & 69.49 & \\
\hline Human labor charges & Reclaimed alkali soils & 163.01 & 174.56 & [53] \\
\hline Machine use charges & Reclaimed alkali soils & 60.62 & 103.34 & \\
\hline Cost of seeds & Reclaimed alkali soils & 15.86 & 7.49 & \\
\hline Cost of plant protection chemicals & Reclaimed alkali soils & 31.03 & 38.21 & \\
\hline Irrigation charges & Reclaimed alkali soils & 36.57 & 47.15 & \\
\hline Micronutrients & Sandy loam clay & 14.25 & 12.49 & [52] \\
\hline Irrigation & Sandy loam clay & 84.07 & 152.13 & \\
\hline Nursery and transplanting/seed and sowing & Sandy loam clay & 21.53 & 65.11 & \\
\hline Cost of weedicides & Reclaimed alkali soils & 33.61 & 26.78 & {$[54]$} \\
\hline Preparatory Tillage & Reclaimed alkali soils & 61.74 & 97.21 & \\
\hline Pre-Sowing Irrigation & Reclaimed alkali soils & 12.80 & 15.70 & \\
\hline Harvesting/threshing & Reclaimed alkali soils & 49.06 & 49.06 & \\
\hline Plant protection & Reclaimed alkali soils & 76.52 & 80.23 & \\
\hline Hoeing and weeding & Reclaimed alkali soils & 37.04 & 18.92 & \\
\hline Irrigation & Reclaimed alkali soils & 76.50 & 125.82 & \\
\hline Fertilizer application & Reclaimed alkali soils & 6.12 & 6.60 & \\
\hline Nitrogen & Reclaimed alkali soils & 17.21 & 19.48 & \\
\hline Phosphate & Reclaimed alkali soils & 15.20 & 20.04 & \\
\hline Zinc sulphate & Reclaimed alkali soils & 7.96 & 8.47 & \\
\hline TYM & Reclaimed alkali soils & 56.30 & 56.30 & \\
\hline Seed & Reclaimed alkali soils & 13.76 & 7.26 & \\
\hline Cost of fertilizers & Reclaimed alkali soils & 49.41 & 48.50 & [53] \\
\hline
\end{tabular}

All the values in $\$$ are converted according to rate of 10 January 2021; 1 Pakistani rupee $=0.0062 \$ ; 1$ Indian Rupee $=0.014 \$$.

Late transplantation of rice due to labor shortage causes heat stress during the reproductive stage; temperatures $>33.7^{\circ} \mathrm{C}$ at anthesis causes panicle sterility due to poor anther dehiscence [55] and $>34^{\circ} \mathrm{C}$ during grain formation substantially reduce grain yield [56]. Temperatures $>35^{\circ} \mathrm{C}$ (above optimal) during reproductive development affect flowering and grain formation in rice [57].

\section{Agricultural Innovations for Sustainable Development of Rice-Wheat Systems}

Adaptation of innovative agricultural practices, such as conservation agriculture (CA), improves and sustains the productivity of RWCS and preserves scarce natural resources, such as water, energy, environmental quality, time, and labor [58]. The adaptation of CA-based systems is most beneficial in extreme climatic conditions, mitigating the negative impact of climatic stresses, such as water and heat stress, and increasing crop yields (0.4-0.8 $\mathrm{t} \mathrm{ha}^{-1}$ per season), when compared with the conventional system [59].

The CA improves energy efficiency and carbon sequestration and reduces GHG emissions [2,60-62]. The incorporation of crop residues favors $\mathrm{N}$ immobilization (biotic and abiotic), which conserves active soil $\mathrm{N}$ by, (i) decomposing crop residues for a source of $\mathrm{C}$ for microorganisms and as an energy source to strengthen their metabolism which results in $\mathrm{N}$ immobilization in biomass, and (ii) incorporating $\mathrm{N}$ into the soil organic matter through ammonium fixation by clay minerals, nitrosation of nitrite with phenolic compounds, and condensation of ammonia with phenol [63].

Immobilized $\mathrm{N}$ can serve as temporary $\mathrm{N}$ sink [63]. Residue retention increases total organic $\mathrm{C}$ and available nutrients, mainly available $\mathrm{P}(16 \%)$, available $\mathrm{K}(12 \%)$, available sulfur $(6 \%)$, and DTPA-extractable $\mathrm{Zn}(11 \%)$, relative to no-residue retention [64]. The adoption of resource-conserving technologies, such as DSR, harvesting rice with advanced rice harvesters, no-till wheat, crop rotation, and precision agriculture for better nutrient 
management, can mitigate climate change, reduce environmental pollution, and conserve natural resources.

\subsection{Direct-Seeded Rice}

In the IGP, increasing shortages of energy, water, and labor force farmers to switch from conventional PTR to a smart seeding system, i.e., DSR. In many studies, DSR produced higher yields, maximum profitability, and water-saving (25\%) than PTR $[62,65,66]$ with improved soil health (Table 3). DSR is an economically feasible alternative as it reduces production costs by $11-17 \%$ (with $25-30 \%$ irrigation water saving) and saves INR 5000 (on fuel and labor) [67] for the same yields as PTR [62]. In a study, DSR used 7-13.9\% less water than the conventional PTR system [68]. Other studies in South Asia have reported that DSR uses 20-57\% less water than PTR [69,70]. Rice produced through DSR also matures earlier than PTR, requires less water, and enables the timely sowing of following wheat and other crops [51].

Table 3. Soil quality in different rice production systems.

\begin{tabular}{|c|c|c|c|c|c|}
\hline Soil Property & Unit & Soil Type & Value in DSR & $\begin{array}{c}\text { Value in } \\
\text { Transplanted Rice }\end{array}$ & Reference \\
\hline Total organic carbon & $\mathrm{g} \mathrm{kg}^{-1}$ & Silt clay & 7.24 & 7.25 & {$[64]$} \\
\hline Aggregate associated carbon & $\mathrm{g} \mathrm{kg}^{-1}$ & Silt clay & 12.56 & 11.94 & \\
\hline Aggregate size class $(0.25-2 \mathrm{~mm})$ & $\%$ & Silt clay & 48 & 48.9 & \\
\hline Mean weight diameter & $\mathrm{mm}$ & Silt clay & 1.61 & 1.61 & \\
\hline Aggregate ratio & & Silt clay & 5.06 & 5.58 & \\
\hline Water stable macro-aggregates & & Silt clay & 83.2 & 83.8 & \\
\hline Water-holding capacity & & Loam & 0.346 & 0.331 & [71] \\
\hline Available water & $\mathrm{cm}^{3} \mathrm{~cm}^{-3}$ & Loam & 0.170 & 0.164 & \\
\hline Geometric mean diameter & $\mathrm{mm}$ & Loam & 0.86 & 0.80 & \\
\hline Soil moisture potential $(75 \mathrm{kPa})$ & & Loam & 0.166 & 0.170 & \\
\hline Crack depth $(60 \mathrm{kPa})$ & $\mathrm{cm}$ & Loam & 13 & 23 & \\
\hline Bulk density $(6-10 \mathrm{~cm})$ & $\mathrm{Mg} \mathrm{m}^{-3}$ & $\begin{array}{c}\text { Clay, silt, } \\
\text { sand }\end{array}$ & 1.60 & 1.61 & [72] \\
\hline WSA $(>0.25 \mathrm{~mm})$ & & $\begin{array}{l}\text { Clay, silt, } \\
\text { sand }\end{array}$ & 67.24 & 64.44 & \\
\hline Steady-state infiltration rate & & $\begin{array}{l}\text { Clay, silt, } \\
\text { sand }\end{array}$ & 0.33 & 0.29 & \\
\hline Water stable micro-aggregates & & Silt clay & 16.8 & 16.2 & {$[64]$} \\
\hline $\mathrm{pH}$ & & Silt clay & 7.39 & 7.41 & \\
\hline Electrical conductivity & $\mathrm{d} S \mathrm{~m}^{-1}$ & Silt clay & 0.79 & 0.75 & \\
\hline Available N & $\mathrm{kg} \mathrm{ha}^{-1}$ & Silt clay & 195.5 & 185.0 & \\
\hline Available P & $\mathrm{kg} \mathrm{ha}^{-1}$ & Silt clay & 28.4 & 27.5 & \\
\hline Available K & $\mathrm{kg} \mathrm{ha}^{-1}$ & Silt clay & 264.3 & 222.4 & \\
\hline Crack width $(60 \mathrm{kPa})$ & $\mathrm{cm}$ & Loam & 3 & 7 & [71] \\
\hline Crack length $(60 \mathrm{kPa})$ & $\mathrm{cm}$ & Loam & 300 & 420 & [71] \\
\hline Total nitrogen & $\mathrm{g} \mathrm{kg}^{-1}$ & Sandy loam & 0.29 & 0.27 & [73] \\
\hline Total soil organic carbon & $\mathrm{g} \mathrm{kg}^{-1}$ & Sandy loam & 3.40 & 3.14 & \\
\hline Soil microbial biomass carbon & $\mu g g^{-1}$ & Sandy loam & 155.6 & 150.28 & \\
\hline Soil microbial biomass nitrogen & $\mu g g^{-1}$ & Sandy loam & 586.3 & 551.78 & \\
\hline Soil aggregates (>0.25 mm) & & Silt loam & 60 & 51 & [69] \\
\hline MWD of soil aggregates & $\mathrm{mm}$ & Silt loam & 1.56 & 1.33 & \\
\hline Bulk density $(0-7 \mathrm{~cm})$ & $\mathrm{Mg} \mathrm{m}^{-3}$ & Silt loam & 1.60 & 1.50 & \\
\hline Penetration resistance $(5-10 \mathrm{~cm})$ & $\mathrm{MPa}$ & Silt loam & 1.2 & 0.75 & \\
\hline
\end{tabular}

WSA, water stable aggregates; MWD, mean weight diameter.

In DSR, the crop is directly sown into the field, avoiding transplantation injuries, thus reducing exposure to terminal drought due to timely stand establishment [74]. Moreover, DSR improves soil health for post-rice winter cereals [3] by enhancing total porosity and decreasing soil bulk density [9], enabling deeper root penetration and facilitating nutrient 
and water uptake [3]. In RWCS, DSR has been reported to reduce methane emissions and production costs, with increased profitability (Table $1 ;$ [51]).

Weeds are a major challenge in DSR; however, the application of weedicides can control the issue. For example, pre-emergence application of pendimethalin $\left(1.5 \mathrm{~kg} \mathrm{ha}^{-1}\right)$ followed by bispyribac-Na $\left(25 \mathrm{~g} \mathrm{ha}^{-1}\right)$ at post-emergence and hand weeding 35 days after sowing provided better weed control and higher rice yields (123-130\%), net returns (327-806\%) and net benefit: cost ratios than PTR [75]. However, diversification of weed flora has been reported in DSR in Pakistan which are very difficult to control and many farmers are afraid to plant rice in the DSR system. This needs the immediate attention of the government agencies in the region.

In conclusion, switching from PTR to DSR in RWCS increases profitability reduces production costs and GHG emissions, and is environmentally friendly, apart from the weed management issue during early growth.

\subsection{Zero-Tillage Wheat}

Using zero tillage (ZT) wheat in RWCS benefits the timeliness of wheat sowing and economics when compared with conventional tillage [59,76]. Zero tillage improves soil health and enhances nutrient concentrations at the soil surface Table $4[77,78]$.

Table 4. Soil quality in different wheat production systems.

\begin{tabular}{|c|c|c|c|c|c|}
\hline Soil Property & Units & Soil Type & Value in $\mathrm{ZT}$ & Value in PT & Reference \\
\hline Bulk density & $\mathrm{Mg} \mathrm{m}^{-3}$ & Siltic soils (Haplic Solonetz) & 1.63 & 1.67 & [2] \\
\hline Soil pH & & Siltic soils (Haplic Solonetz) & 7.84 & 8.06 & \\
\hline EC & $\mathrm{dS} \mathrm{m}^{-1}$ & Siltic soils (Haplic Solonetz) & 0.25 & 0.21 & \\
\hline Total N & $\%$ & Silty soils (Haplic Solonetz) & 0.19 & 0.14 & \\
\hline Bulk density & $\mathrm{Mg} \mathrm{m}^{-3}$ & Sandy loam & 1.54 & 1.50 & [79] \\
\hline Infiltration rate & $\mathrm{mm} \mathrm{h}^{-1}$ & Sandy loam & 1.5 & 0.3 & \\
\hline MWD & $\mathrm{mm}$ & Sandy loam & 1.9 & 1.7 & \\
\hline WSA (>0.25 mm) & $\%$ & Sandy loam & 73 & 57 & \\
\hline Bulk density & $\mathrm{Mg} \mathrm{m}^{-3}$ & Sandy loam & 1.24 & 1.38 & [80] \\
\hline Soil temperature & ${ }^{\circ} \mathrm{C}$ & Sandy loam & 33.15 & 35.29 & \\
\hline PAWC $(0-15 \mathrm{~cm})$ & $\mathrm{mm}$ & Sandy loam & 16.70 & 14.7 & \\
\hline Infiltration rate & $\mathrm{mm} \mathrm{h}^{-1}$ & Sandy loam & 9.58 & 11.40 & \\
\hline Bulk density & $\mathrm{Mg} \mathrm{m}^{-3}$ & Sandy loam & 1.52 & 1.48 & [81] \\
\hline Infiltration rate & $\mathrm{mm} \mathrm{h}^{-1}$ & Sandy loam to loam & 18.0 & 42.0 & [66] \\
\hline$\beta$-Glucosidase (p-NP) & $\mu g^{-1} h^{-1}$ & Loam & 51.24 & 36.23 & [82] \\
\hline Bulk density & $\mathrm{Mg} \mathrm{m}^{-3}$ & Sandy loam & 1.44 & 1.46 & [83] \\
\hline Earthworm count & $\mathrm{ha}^{-1}$ & Sandy loam & 380,000 & 60,000 & [84] \\
\hline Dehydrogenase activity & $\mu \mathrm{g} \mathrm{g}^{-1} \mathrm{~d}^{-1}$ & Sandy loam & 166.6 & 29.5 & \\
\hline SOC & $\mathrm{g} \mathrm{kg}^{-1}$ & Sandy loam & 2.51 & 1.47 & \\
\hline Bulk density & $\mathrm{Mg} \mathrm{m}^{-3}$ & Sandy loam & 1.60 & 1.56 & [68] \\
\hline SOC stock & $\mathrm{kg} \mathrm{m}^{-3}$ & Sandy loam & 6.88 & 5.91 & \\
\hline Oxidizable organic C & $\mathrm{g} \mathrm{kg}^{-1}$ & Fine loam (Typic Natrustalf) & 8.1 & 4.9 & [85] \\
\hline WSA $(>0.25 \mathrm{~mm})$ & $\%$ & Sandy loam & 70 & 59 & [69] \\
\hline MWD & $\mathrm{mm}$ & Sandy loam & 2.68 & 1.62 & \\
\hline Infiltration rate & $\mathrm{mm} \mathrm{h}^{-1}$ & Sandy loam & 5.0 & 4.7 & \\
\hline Bulk density & $\mathrm{Mg} \mathrm{m}^{-3}$ & Sandy loam & 1.52 & 1.57 & \\
\hline Crack width & $\mathrm{cm}$ & Sandy loam (typic ustrochrept) & 0.53 & 2.68 & [86] \\
\hline Least limiting water range & $\%$ & Sandy loam & 6.2 & 3.3 & [72] \\
\hline WSA $(>0.25 \mathrm{~mm})$ & $\%$ & Sandy loam & 67.24 & 52.66 & \\
\hline Bulk density & $\mathrm{Mg} \mathrm{m}^{-3}$ & Sandy loam & 1.55 & 1.48 & \\
\hline Infiltration rate & $\mathrm{mm} \mathrm{h}^{-1}$ & Sandy loam & 3.3 & 1.8 & \\
\hline Penetration resistance & $\mathrm{MPa}$ & Sandy loam & 1.4 & 1.0 & \\
\hline Volume of crack $\left(\times 10^{-4}\right)$ & $\mathrm{m}^{3} \mathrm{~m}^{-2}$ & Clayey & 77.21 & 55.57 & [87] \\
\hline Bulk density & $\mathrm{Mg} \mathrm{m}^{-3}$ & Clay & 1.5 & 1.5 & [88] \\
\hline
\end{tabular}


Table 4. Cont.

\begin{tabular}{|c|c|c|c|c|c|}
\hline Soil Property & Units & Soil Type & Value in $\mathrm{ZT}$ & Value in PT & Reference \\
\hline Infiltration rate & $\mathrm{mm} \mathrm{h}^{-1}$ & Clay & 17.30 & 15.55 & \\
\hline PAWC $(0-15 \mathrm{~cm})$ & $\mathrm{mm}$ & Clay & 40 & 36 & \\
\hline Bulk density & $\mathrm{Mg} \mathrm{m}^{-3}$ & Clay & 1.24 & 1.28 & [89] \\
\hline WSA $(>0.25 \mathrm{~mm})$ & $\%$ & Clay & 60.47 & 51.36 & \\
\hline $\begin{array}{l}\text { Alkaline phosphatase } \\
\text { (p-nitrophenol) }(0-10 \mathrm{~cm})\end{array}$ & $\mu g g^{-1} h^{-1}$ & Silty clay & 287.7 & 269.8 & [90] \\
\hline Carbon build up & $\%$ & Silty clay & 14.56 & 5.44 & \\
\hline Fluorescein diacetate activity & $\mathrm{mg} \mathrm{kg}^{-1} \mathrm{~h}^{-1}$ & Silty clay & 49.54 & 43.54 & \\
\hline Bulk density & $\mathrm{Mg} \mathrm{m}^{-3}$ & Illitic, Ustic Typic Calciorthent & 1.46 & 1.55 & [91] \\
\hline Carbon input addition & $\mathrm{Mg} \mathrm{h}^{-1}$ & Illitic, Ustic Typic Calciorthent & 14.64 & 3.10 & \\
\hline Fluorescein diacetate activity & $\mu g g^{-1} h^{-1}$ & Mixed loamy sand & 27.9 & 13.3 & [92] \\
\hline Total C & $\mathrm{g} \mathrm{kg}^{-1}$ & Sandy clay loam & 7.25 & 6.95 & [93] \\
\hline $\mathrm{KMnO}_{4} \mathrm{C}$ & $\mathrm{g} \mathrm{kg}^{-1}$ & Sandy clay loam & 0.43 & 0.39 & \\
\hline Soil water retention & $\mathrm{mm}$ & sandy clay loam & 4.6 & 4.2 & [94] \\
\hline WSA (>0.25 mm) & $\%$ & Sandy loam (Typic Ustochrept) & 77.3 & 68.4 & [95] \\
\hline MWD & $\mathrm{mm}$ & Sandy loam & 0.74 & 0.71 & [96] \\
\hline Effective porosity & $\%$ & Sandy loam & 18.7 & 17.4 & \\
\hline Bulk density & $\mathrm{Mg} \mathrm{m}^{-3}$ & Sandy loam & 1.43 & 1.39 & \\
\hline Active C & $\mathrm{g} \mathrm{kg}^{-1}$ & Sandy loam (Typic Ustochrept) & 4.09 & 2.92 & [95] \\
\hline MWD & $\mathrm{mm}$ & Sandy loam (Typic Ustochrept) & 1.21 & 0.92 & \\
\hline Total organic carbon & $\mathrm{g} \mathrm{kg}^{-1}$ & Fluvisol (silty clay) & 7.25 & 6.38 & {$[64]$} \\
\hline $\begin{array}{l}\text { Saturated hydraulic } \\
\text { conductivity }\left(\times 10^{-6}\right)\end{array}$ & $\mathrm{m} \mathrm{s}^{-1}$ & Clay & 7.32 & 2.13 & [97] \\
\hline MWD & $\mathrm{mm}$ & Clay & 0.94 & 0.76 & \\
\hline MWD & $\mathrm{mm}$ & Silty loam (Typic Ustocrept) & 1.86 & 0.95 & [17] \\
\hline WSA $(>0.25 \mathrm{~mm})$ & $\%$ & Silty loam (Typic Ustocrept) & 96 & 84 & \\
\hline SOC & $\mathrm{g} \mathrm{kg}^{-1}$ & Silty loam (Typic Ustocrept) & 7.86 & 5.81 & \\
\hline Bulk density & $\mathrm{Mg} \mathrm{m}^{-3}$ & Sandy loam & 1.60 & 1.56 & [98] \\
\hline MWD & $\mathrm{mm}$ & Sandy loam & 0.95 & 0.79 & [99] \\
\hline Porosity & $\%$ & Clay loam & 42.40 & 42.62 & {$[60]$} \\
\hline Bulk density & $\mathrm{Mg} \mathrm{m}^{-3}$ & Clay loam & 1.43 & 1.40 & \\
\hline Soil moisture (\%) & & $\begin{array}{c}\text { Non-calcareous brown sandy } \\
\text { loam Haplaquept }\end{array}$ & 18.6 & 7.4 & [100] \\
\hline
\end{tabular}

EC, electrical conductivity; MWD, mean weight diameter; WSA, water stable aggregates; PAWC, plant available water capacity; BD, bulk density; SOC, soil organic carbon; ZT, zero tillage; PT, plow tillage.

Sowing wheat with ZT ensures early sowing and suppresses the obnoxious weed e.g., littleseed canarygrass (68-80\% reduction in population) when compared with conventional farmers' practices [101]. Moreover, ZT facilitates the timeliness of wheat sowing [3], improves soil structure, fertility, soil biological activities [102], and water-stable aggregates [103], and reduces the costs of land preparation [73,104]. In ZT wheat, the activities of soil microbial biomass carbon [73,105], soil enzymes [106], soil respiration [66], and soil quality index [107] are higher than plow tillage. In no-till with permanent soil cover, water infiltration is usually higher than plow tillage [108].

The Happy Seeder is a zero-tillage seeder that sows wheat into large amounts of crop residue and saves $\$ 136 \mathrm{ha}^{-1}$. Moreover, it facilitates timely wheat sowing, saves water, reduces air pollution, and enhances the sustainability of agriculture [24]. The use of Happy Seeder reduces the labor requirement for crop establishment by $80 \%$, herbicide use by $50 \%$, and irrigation by $20-25 \%$ [109]. Use of zero-tillage drill and Happy Seeder made it easy to plant wheat 2.7 days earlier (with earlier stand establishment) than that in CT wheat [24]. Many farmers in RWCS in South Asia are quickly shifting towards Happy Seeder wheat sowing due to the short turnover time between rice harvest and wheat sowing and imposition of huge penalties on the burning of rice residues. In conclusion, switching wheat sowing from conventional tillage to ZT ensures timely wheat sowing, saves production costs and improves soil health, yields, and yield sustainability. 


\subsection{Promotion of Precision Agriculture Practices for Nutrient Management}

In the IGP, fertilizer recommendations are based on crop response data without considering the inherent nutrient supply capacity of the soil, causing over- or underfertilization [68]. Improved nutrient management under CA improves yields and nutrient and water use efficiencies [110]. For RWCS in the IGP, a combination of macro- and microfertilizers with green manure, crop residues, and organic manures is a practical option for better nutrient management [111].

In maize-wheat-mungbean rotations, the adoption of ZT with site-specific nutrient management improved the soil physical, chemical, and biological properties, i.e., waterstable aggregates, saturated hydraulic conductivity, soil organic $\mathrm{C}$, available $\mathrm{N}, \mathrm{P}$, and $\mathrm{K}$, microbial biomass $\mathrm{C}$, and enzyme activities (dehydrogenase, alkaline phosphatase, and $\beta$-glucosidase), relative to conventional and unfertilized treatments [112].

A recent study on $\mathrm{N}$ application rates in RWCS recommended $\mathrm{N}$ application rates of 120-200 kg ha ${ }^{-1}$ for rice and 50-185 $\mathrm{kg} \mathrm{ha}^{-1}$ for wheat [26]. Zinc (Zn) application at $25 \mathrm{~kg} \mathrm{ha}^{-1}$ as $_{\mathrm{ZnSO}}$ improved rice and wheat yields [113]. In another study, the application of Zn improved the grain yields in both DSR and PTR systems [114]. Likewise, the boron (B) application to soils deficient in B improved growth and grain yield of rice $[115,116]$.

Leaf color charts and SPAD chlorophyll meters are good options for managing $\mathrm{N}$ application, with a strong correlation $(0.84-0.91)$ reported between these and various rice and wheat genotypes. Moreover, net returns increased by $19-31 \%$ using a leaf color chart for $\mathrm{N}$ management rather than a fixed $\mathrm{N}$ application rate [68].

In conclusion, integrated nutrient management, crop rotations incorporating legumes, site-specific optimization of nutrients rates, and the use of SPAD chlorophyll meters and leaf color charts are the best options for nutrient management and enhanced nutrient use efficiencies in rice and wheat.

\subsection{Planning Wise Crop Rotations}

Continuous monocultures have caused nutrient imbalances and increased the risk of pest and disease occurrence [59]. Diversifying the area sown to rice to incorporate other remunerative crops sustains soil fertility and improves crop productivity and farmer income [66]. Rotating cereals and pulses help to maintain soil quality and soil microflora and fauna [66,107]. It has been reported that the inclusion of leguminous crops in the cereal system increased system productivity by $18 \%$ and net returns by $15 \%$ [117]. In another study, the CA-based rice-wheat-mungbean cropping system improved system productivity by $11 \%$ and profitability by $24 \%$, and reduced energy inputs by $25 \%$, relative to a conventional rice-wheat system [62].

Long-term crop rotations (2000-2004) in India revealed that the rice-potato-green gram rotation had the highest net returns, system productivity, production efficiency, benefit: cost ratio, and profitability. Moreover, the inclusion of summer grain/fodder legumes improved soil organic matter [118]. The addition of short-duration summer legumes (mungbean and cowpea) in RWCS enhanced system productivity and profitability and nutritional security [119]. A rice-fallow cropping system with the intensification of five winter crop rotations (chickpea, lentil, safflower, linseed, and mustard) resulted in higher productivity for grain legumes (chickpea and lentil) than oilseed crops (safflower, mustard, and linseed) [120].

The inclusion of legumes in the cereal system fixes atmospheric $\mathrm{N}$ and improves soil fertility through nutrient recycling from deeper soil layers and mycorrhizal colonization [86]. Legume residues contain $20-80 \mathrm{~kg} \mathrm{~N} \mathrm{ha}^{-1}$ (70\% derived from $\mathrm{N}$ fixation), depending on the crop type [121,122]. A long-term study (2001-2004) showed that ricelegume rotations improved rice yields more than a rice-fallow rotation. In conclusion, the inclusion of short-duration grain or forage legumes in rotation in RWCS improves soil fertility and the yield of succeeding crops. 


\subsection{Rice Harvesting with Advanced Rice Harvesters}

Rice harvesting is the most expensive rice production field activity, as the timing, duration, and mode of conduct of the harvesting directly affect rice quality, efficiencies, and farmer incomes [123]. In developing countries, rice is manually harvested with hand tools (as sickles) and threshed by beating on a hard matter or durum. The harvesting of rice with modern rice harvesters saves time, costs, and labor and reduces grain losses when compared with conventional manual harvesting [124]. Modern crop-specific mechanical harvesters, such as combine and mini-combine harvesters and reapers, can save time and labor, reduce harvesting losses, and increase profit margins and rice quality [125]. A reaper saved $37 \%$ and mini-combine harvesters saved $52 \%$ of harvesting costs over manual harvesting [126]. On average, a mini-combine harvester saves $95.5 \%$ of the time, $61.5 \%$ of costs, and $4.9 \%$ of grain losses compared with manual harvesting [127].

Combine harvesters (mini, medium, and large) are a time-saving technology, saving $20-30 \%$ of operation time than ordinary machines [128]. The use of a mini-combine harvester or reaper saved $65 \%$ and $52 \%$ of the labor costs over manual harvesting [129]. A combine harvester increased the net benefit by $30.3 \%$, relative to manual harvesting and threshing [130]. Likewise, a vertical conveyor reaper saved $44 \%$ of harvesting costs [131]. Mechanical harvesting can also save grain losses, which were $2.88-3.60 \%$ for a tractormounted combine harvester [125], compared with $6.36 \%$ for manual harvesting [132].

However, in Pakistan and many other countries of South Asia, rice crop is harvested through wheat combine harvesters through some modification in machines. The use of wheat combine harvester in rice cause substantial grain losses which affect farmer profitability. In a study, the use of rice specific harvester reduces harvest losses by $14 \%$ and an extra premium of $5 \%$ on the paddy harvested from rice harvesters which increased farmer profitability [133]. In conclusion, rice harvesting with specific rice harvesters improves grain quality, reduces grain losses, and increases profit. However, the price of advanced rice harvesters is not affordable for all farmers. But this problem can be solved through the subsidy by the governments or and through cooperative investment, where a group of farmers pool their resources to purchase such machinery. Provision of such machinery by the service providers, on rental basis, can be another option. However, the rental charges for rice harvesters are double than the old model combine wheat harvesters. Therefore, private investors are interested to invest in the purchase and provision of on-farm services to farmers in South Asia.

\section{Conclusions}

The RWCS is the major cereal-based cropping system in South Asia, providing food to millions of people. However, the sustainability and productivity of this system are at high risk due to climate change, deteriorating natural resources, yield stagnation, and the negative impacts of this system on the environment. Major issues with this system include GHG emissions, declining soil quality and health, and reduced profit margins. However, the adoption of alternative innovative and sustainable approaches, including smart seeding/DSR, ZT wheat, crop rotation, precision agriculture, and rice and wheat harvesting using advanced harvesters such as the reaper, mini, and combine harvesters are the best options for improving yield, grain quality, and soil health, reducing environmental pollution, and preserving the ecosystem and natural resources (i.e., water, air, and soil).

Author Contributions: Conceptualization: K.H.M.S., M.F.; methodology: all; formal analysis: all; investigation: all; writing—original draft preparation: K.H.M.S., M.F.; writing-review and editing: all. All authors have read and agreed to the published version of the manuscript.

Funding: This research received no external funding.

Institutional Review Board Statement: Not applicable.

Informed Consent Statement: Not applicable.

Data Availability Statement: Not applicable. 
Conflicts of Interest: The authors declare no conflict of interest.

\section{References}

1. Ray, D.K.; Ramankutty, N.; Mueller, N.D.; West, P.C.; Foley, J.A. Recent patterns of crop yield growth and stagnation. Nat. Commun. 2012, 3, 1293. [CrossRef]

2. Jat, H.S.; Datta, A.; Sharma, P.C.; Kumar, V.; Yadav, A.K.; Choudhary, M.; Choudhary, V.; Gathala, M.K.; Sharma, D.K.; Jat, M.L.; et al. Assessing soil properties and nutrient availability under conservation agriculture practices in a reclaimed sodic soil in cereal-based systems of North-West India. Arch. Agron. Soil Sci. 2018, 64, 531-545. [CrossRef] [PubMed]

3. Nawaz, A.; Farooq, M.; Nadeem, F.; Siddique, K.H.; Lal, R. Rice-wheat cropping systems in South Asia: Issues, options and opportunities. Crop Pasture Sci. 2019, 70, 395-427. [CrossRef]

4. Humphreys, E.; Kukal, S.S.; Christen, E.W.; Hira, G.S.; Sharma, R.K. Halting the groundwater decline in north-west India-Which crop technologies will be winners? Advan. Agron. 2010, 109, 155-217.

5. $\quad$ Bhushan, L.; Ladha, J.K.; Gupta, R.K.; Singh, S.; Tirol-Padre, A.; Saharawat, Y.S.; Gathala, M.; Pathak, H. Saving of water and labor in a rice-wheat system with no-tillage and direct seeding technologies. Agron. J. 2007, 99, 1288-1296. [CrossRef]

6. Geethalakshmi, V.; Ramesh, T.; Palamuthirsolai, A.; Lakshmanan. Agronomic evaluation of rice cultivation systems for water and grain productivity. Arch. Agron. Soil Sci. 2011, 57, 159-166. [CrossRef]

7. Tuong, T.P.; Bouman, B.A.M. Rice production in water-scarce environments. In Water Productivity in Agriculture: Limits and Opportunities for Improvement; Kijne, J.W., Barker, R., Molden, D., Eds.; CABI: Wallingford, UK, 2003; pp. 53-67.

8. Brown, L.; Black, B.; Hassan, G.; Hussein, G. Aquifer depletion. In Encyclopedia of Earth; Cleveland, C.J., Ed.; Environmental Information Coalition and National Council for Science and the Environment: Washington, DC, USA, 2011.

9. Farooq, M.; Nawaz, A. Weed dynamics and productivity of wheat in conventional and conservation rice-based cropping systems. Soil Tillage Res. 2014, 141, 1-9. [CrossRef]

10. Ishaq, M.; Ibrahim, M.; Hassan, A.; Saeed, M.; Lal, R. Subsoil compaction effects on crops in Punjab, Pakistan: II. Root growth and nutrient uptake of wheat and sorghum. Soil Tillage Res. 2001, 60, 153-161. [CrossRef]

11. Yadav, A.; Malik, R.K. Herbicide Resistant Phalaris Minorin Wheat-A Sustainability Issue; Department of Agronomy and Directorate of Extension Education, CCS Haryana Agricultural University: Hisar, India, 2005.

12. Chhokar, R.S.; Singh, S.; Sharma, R.K. Herbicides for control of isoproturon-resistant Littleseed Canarygrass (Phalaris minor) in wheat. Crop Prot. 2008, 27, 719-726. [CrossRef]

13. Ranjit, J.D. Weeds and weed management in the rice-wheat system. In Proceedings Rice-Wheat Research End-of-Project Workshop; Hobbs, P.R., Rajbhandary, N.P., Eds.; NARC/CIMMYT/RWC: Kathmandu, Nepal, 1997; pp. 13-22.

14. Bhatt, R.; Kukal, S.S.; Busari, M.A.; Arora, S.; Yadav, M. Sustainability issues on rice-wheat cropping system. Int. Soil Water Conserv. Res. 2016, 4, 64-74. [CrossRef]

15. Nayyar, V.K. Soil micronutrient deficiencies in the rice-wheat cropping system. In Addressing Resource Conservation Issues in Rice-Wheat Systems of South Asia: A Resource Book; Rice-Wheat Consortium for the Indo-Gangetic Plains: New Delhi, India, 2003; pp. 157-162.

16. Alam, M.M.; Ladha, J.K.; Rahman, Z.; Khan, S.R.; Khan, A.; Buresh, R. Nutrient management for increased productivity of rice-wheat cropping system in Bangladesh. Field Crop. Res. 2006, 96, 374-386. [CrossRef]

17. Bhattacharyya, T.; Pal, D.K.; Ray, S.K.; Chandran, P.; Mandal, C.; Telpande, B.; Deshmukh, A.S.; Tiwary, P. Simulating change in soil organic carbon in two long term fertilizer experiments in India: With the RothC model. Clim. Change Environ. Sustain. 2013, 1, 104-117. [CrossRef]

18. Sharma, V.; Hussain, S.; Sharma, K.R.; Arya, V.M. Labile carbon pools and soil organic carbon stocks in the foothill Himalayas under different land use systems. Geoderma 2014, 232, 81-87. [CrossRef]

19. Bhatia, A.; Pathak, H.; Jain, N.; Singh, P.K.; Singh, A.K. Global warming potential of manure amended soils under rice-wheat system in the Indo-Gangetic plains. Atmos. Environ. 2005, 39, 6976-6984. [CrossRef]

20. Pathak, H.; Bhatia, A.; Prasad, S.; Singh, S.; Kumar, S.; Jain, M.C.; Kumar, U. Emission of nitrous oxide from rice-wheat systems of Indo-Gangetic plains of India. Environ. Monit. Assess. 2002, 77, 163-178. [CrossRef]

21. Van Groenigen, J.W.; Velthof, G.L.; Oenema, O.; Van Groenigen, K.J.; Van Kessel, C. Towards an agronomic assessment of $\mathrm{N}_{2} \mathrm{O}$ emissions: A case study for arable crops. Eur. J. Soil Sci. 2010, 61, 903-913. [CrossRef]

22. Malla, G.; Bhatia, A.; Pathak, H.; Prasad, S.; Jain, N.; Singh, J. Mitigating nitrous oxide and methane emissions from soil in rice-wheat system of the Indo-Gangetic plain with nitrification and urease inhibitors. Chemosphere 2005, 58, 141-147. [CrossRef]

23. NAAS. Innovative Viable Solution to Rice Residue Burning in Rice-Wheat Cropping System through Concurrent Use of Super Straw Management System-Fitted Combines and Turbo Happy Seeder. Policy Brief No. 2. National Academy of Agricultural Sciences. Available online: https:/ / naasindia.org/documents/CropBurning.pdf (accessed on 10 September 2019).

24. Keil, A.; Krishnapriya, P.P.; Mitra, A.; Jat, M.L.; Sidhu, H.S.; Krishna, V.V.; Shyamsundar, P. Changing agricultural stubble burning practices in the Indo-Gangetic plains: Is the Happy Seeder a profitable alternative? Int. J. Agric. Sustain. 2020, 1-24. [CrossRef]

25. Lohan, S.K.; Jat, H.S.; Yadav, A.K.; Sidhu, H.S.; Jat, M.L.; Choudhary, M.; Peter, J.K.; Sharma, P.C. Burning issues of paddy residue management in north-west states of India. Renew. Sustain. Energy Rev. 2018, 81, 693-706. [CrossRef] 
26. Sapkota, T.B.; Singh, L.K.; Yadav, A.K.; Khatri-Chhetri, A.; Jat, H.S.; Sharma, P.C.; Jat, M.L.; Stirling, C.M. Identifying optimum rates of fertilizer nitrogen application to maximize economic return and minimize nitrous oxide emission from rice-wheat systems in the Indo-Gangetic Plains of India. Arch. Agron. Soil Sci. 2020, 7, 1-6. [CrossRef]

27. Gupta, D.K.; Bhatia, A.; Kumar, A.; Das, T.K.; Jain, N.; Tomer, R.; Malyan, S.K.; Fagodiya, R.K.; Dubey, R.; Pathak, H. Mitigation of greenhouse gas emission from rice-wheat system of the Indo-Gangetic plains: Through tillage, irrigation and fertilizer management. Agric. Ecosyst. Environ. 2016, 230, 1-9. [CrossRef]

28. Liu, S.; Zhang, Y.; Lin, F.; Zhang, L.; Zou, J. Methane and nitrous oxide emissions from direct-seeded and seedling-transplanted rice paddies in southeast China. Plant Soil 2014, 374, 285-297. [CrossRef]

29. Saharawat, Y.S.; Ladha, J.K.; Pathak, H.; Gathala, M.K.; Chaudhary, N.; Jat, M.L. Simulation of resource-conserving technologies on productivity, income and greenhouse gas GHG emission in rice-wheat system. J. Soil Sci. Environ. Manag. $2012,3,9-22$.

30. Pathak, H.; Chakrabarti, B.; Bhatia, A.; Jain, N.; Aggarwal, P.K. Potential and cost of low carbon technologies in rice and wheat systems: A case study for the Indo-Gangetic Plains. In Low Carbon Technologies for Agriculture: A Study on Rice and Wheat Systems in the Indo-Gangetic Plains; Pathak, H., Aggarwal, P.K., Eds.; Indian Agriculture Research Institute: New Delhi, India, 2012; pp. 12-40.

31. Tirol-Padre, A.; Rai, M.; Kumar, V.; Gathala, M.; Sharma, P.C.; Sharma, S.; Nagar, R.K.; Deshwal, S.; Singh, L.K.; Jat, H.S.; et al. Quantifying changes to the global warming potential of rice wheat systems with the adoption of conservation agriculture in northwestern India. Agric. Ecosyst. Environ. 2016, 219, 125-137. [CrossRef]

32. Pathak, H.; Saharawat, Y.S.; Gathala, M.K.; Mohanty, S.; Ladha, J.K. Simulating environmental impact of resource-conserving technologies in the rice-wheat system of the Indo-Gangetic Plains. In Integrated Crop and Resource Management in the Rice-Wheat System of South Asia; Ladha, J.K., Singh, Y., Erenstein, O., Hardy, B., Eds.; International Rice Research Institute: Los Baños, PH, USA, 2009; pp. 321-333.

33. Singh, S.K.; Bharadwaj, V.; Thakur, T.C.; Pachauri, S.P.; Singh, P.P.; Mishra, A.K. Influence of crop establishment methods on methane emission from rice fields. Curr. Sci. 2009, 97, 84-89.

34. Pathak, H.; Aggarwal, P.K.; Roetter, R.P.; Kalra, N.; Bandyopadhaya, S.K.; Prasad, S.; Van Keulen, H. Modelling the quantitative evaluation of soil nutrient supply, nutrient use efficiency, and fertilizer requirements of wheat in India. Nutr. Cycl. Agroecosyst. 2003, 65, 105-113. [CrossRef]

35. Ishibashi, E.; Yamamoto, S.; Akai, N.; Tsuruta, H. The influence of no-tilled direct seeding cultivation on greenhouse gas emissions from rice paddy fields in Okayama, Western Japan. 4. Major factors controlling nitrous oxide emission from rice paddy fields under no-till direct seeding cultivation. Jpn. J. Soil Sci. Plant Nutr. 2007, 78, 453-463.

36. Setyanto, P.; Makarim, A.K.; Fagi, A.M.; Wassmann, R.; Buendia, L.V. Crop management affecting methane emissions from irrigated and rainfed rice in Central Java (Indonesia). Nutr. Cycl. Agroecosyst. 2000, 58, 85-93. [CrossRef]

37. Corton, T.M.; Bajita, J.B.; Grospe, F.S.; Pamplona, R.R.; Assis, C.A.; Wassmann, R.; Lantin, R.S.; Buendia, L.V. Methane emission from irrigated and intensively managed rice fields in Central Luzon (Philippines). Nutr. Cycl. Agroecosyst. 2000, 58, 37-53. [CrossRef]

38. Jat, M.L.; Gathala, M.K.; Saharawat, Y.S.; Tetarwal, J.P.; Gupta, R. Double no-till and permanent raised beds in maize-wheat rotation of north-western IndoGangetic plains of India: Effects on crop yields, water productivity, profitability and soil physical properties. Field Crop. Res. 2013, 149, 291-299. [CrossRef]

39. Verburg, P.H.; van Bodegom, P.M.; van der Gon, H.A.; Bergsma, A.; van Breemen, N. Upscaling regional emissions of greenhouse gases from rice cultivation: Methods and sources of uncertainty. Plant Ecol. 2006, 182, 89-106. [CrossRef]

40. IPCC. The physical science basis. In Contribution of Working Group I to the Fourth Assessment Report of the Intergovernmental Panel on Climate Change; Cambridge University Press: Cambridge, UK, 2007.

41. Shindell, D.T.; Faluvegi, G.; Koch, D.M.; Schmidt, G.A.; Unger, N.; Bauer, S.E. Improved attribution of climate forcing to emissions. Science 2009, 326, 716-718. [CrossRef]

42. Pathak, H.; Bhatia, A.; Jain, N. Greenhouse Gas Emission from Indian Agriculture: Trends, Mitigation and Policy Needs; Approach Paper; Indian Agricultural Research Institute: New Delhi, India, 2014.

43. Tandon, H.L.S.; Sekhon, G.S. Potassium Research and Agricultural Production in India; Fertilizer Development and Consultation Organization: New Delhi, India, 1988.

44. Sharma, P.K.; Nayyar, V.K. Diagnosing Micronutrient Related Constraints to Productivity in Muktsar, Patiala, Hoshiarpur and Ludhiana Districts; Project Report for ITSAP (Information Technology for Sustainable Agriculture in Punjab)—UNDP-TIFAC Sponsored Project; Punjab Remote Sensing Centre: Ludhiana, India, 2004.

45. Chander, S. Annual review of fertilizer production and consumption. Indian J. Fertil. 2011, 7, 141-188.

46. Nayyar, V.K.; Arora, C.L.; Kataki, P.K. Management of soil micronutrient deficiencies in the rice-wheat cropping system. J. Crop. Prod. 2001, 4, 87-131. [CrossRef]

47. Singh, M.V. Micronutrient deficiencies in crops and soils in India. In Micronutrient Deficiencies in Global Crop Production; Alloway, B.J., Ed.; Springer: Dordrecht, The Netherlands, 2008; pp. 93-125.

48. Singh, V.K.; Dwivedi, B.S.; Shukla, A.K.; Chauhan, Y.S.; Yadav, R.L. Diversification of rice with pigeonpea in a rice-wheat cropping system on a Typic Ustochrept: Effect on soil fertility, yield and nutrient use efficiency. Field Crops Res. 2005, 92, 85-105. [CrossRef] 
49. Sapkota, T.B.; Majumdar, K.; Jat, M.L.; Kumar, A.; Bishnoi, D.K.; McDonald, A.J.; Pampolino, M. Precision nutrient management in conservation agriculture based wheat production of Northwest India: Profitability, nutrient use efficiency and environmental footprint. Field Crops Res. 2014, 155, 233-244. [CrossRef]

50. Pandey, S.; Velasco, L.E. Economics of direct seeding in Asia: Patterns of adaptation and research priorities. Int. Rice Res. Notes 1999, 24, 6-11.

51. Farooq, M.; Siddique, H.M.K.; Rehman, H.; Aziz, T.; Lee, D.; Wahid, A. Rice direct seeding: Experiences, challenges and opportunities. Soil Tillage Res. 2011, 111, 87-98. [CrossRef]

52. Younas, M.; Rehman, M.A.; Hussain, A.; Ali, L.; Waqar, M.Q. Economic comparison of direct seeded and transplanted rice: Evidences from adaptive research area of Punjab Pakistan. Asian J Agri. Biol. 2015, 4, 1-7.

53. Tripathi, J.N.; Lorenzen, J.; Bahar, O.; Ronald, P.; Tripathi, L. Transgenic expression of the rice Xa21 pattern-recognition receptor in banana (Musa sp.) confers resistance to Xanthomonas campestris pv. musacearum. Plant Biotech. J. 2014, 12, 663-673. [CrossRef]

54. Kumar, R.; Batra, S.C. Economic and Constraint Analysis of Rice Cultivation by DSR Technology in Karnal District of Haryana. Adv. Econ. Bus. Manag. 2017, 4, 61-64.

55. Jagadish, S.V.; Craufurd, P.Q.; Wheeler, T.R. High temperature stress and spikelet fertility in rice (Oryza sativa L.). J. Exp. Bot. 2007, 58, 1627-1635. [CrossRef]

56. Morita, S.; Shiratsuchi, H.; Takanashi, J.; Fujita, K. Effect of high temperature on ripening in rice plants: Comparison of the effects of high night temperatures and high day temperatures. Jpn. J. Crop Sci. 2002, 71, 102-109. [CrossRef]

57. Kumar, N.; Kumar, N.; Shukla, A.; Shankhdhar, S.C.; Shankhdhar, D. Impact of terminal heat stress on pollen viability and yield attributes of rice (Oryza sativa L.). Cereal Res. Commun. 2015, 43, 616-626. [CrossRef]

58. Dikgwatlhe, S.B.; Chen, Z.D.; Lal, R.; Zhang, H.L.; Chen, F. Changes in soil organic carbon and nitrogen as affected by tillage and residue management under wheat-maize cropping system in the North China Plain. Soil Tillage Res. 2014, 144, 110-118. [CrossRef]

59. Jat, M.L.; Chakraborty, D.; Ladha, J.K.; Rana, D.S.; Gathala, M.K.; McDonald, A.; Gerard, B. Conservation agriculture for sustainable intensification in South Asia. Nat. Sustain. 2020, 3, 336-343. [CrossRef]

60. Jat, R.D.; Nanwal, R.K.; Jat, H.S.; Bishnoi, D.K.; Dadarwal, R.S.; Kakraliya, S.K.; Yadav, A.; Choudhary, K.M.; Jat, M.L. Effect of conservation agriculture and precision nutrient management on soil properties and carbon sustainability index under maizewheat cropping sequence. Int. J. Chem. Stud. 2017, 5, 1746-1756.

61. Jat, R.D.; Jat, H.S.; Nanwal, R.K.; Yadav, A.K.; Bana, A.; Choudhary, K.M.; Kakraliya, S.K.; Sutaliya, J.M.; Sapkota, T.B.; Jat, M.L. Conservation agriculture and precision nutrient management practices in maize-wheat system: Effects on crop and water productivity and economic profitability. Field Crop. Res. 2018, 222, 111-120. [CrossRef]

62. Kumar, V.; Jat, H.S.; Sharma, P.C.; Gathala, M.K.; Malik, R.K.; Kamboj, B.R.; Yadav, A.K.; Ladha, J.K.; Raman, A.; Sharma, D.K.; et al. Can productivity and profitability be enhanced in intensively managed cereal systems while reducing the environmental footprint of production? Assessing sustainable intensification options in the breadbasket of India. Agric. Ecosyst. Environ. 2018, 252, 132-147. [CrossRef] [PubMed]

63. Yansheng, C.; Fengliang, Z.; Zhongyi, Z.; Tongbin, Z.; Huayun, X. Biotic and abiotic nitrogen immobilization in soil incorporated with crop residue. Soil Tillage Res. 2020, 202, 104664. [CrossRef]

64. Nandan, R.; Singh, V.; Singh, S.S.; Kumar, V.; Hazra, K.K.; Nath, C.P.; Poonia, S.; Malik, R.K.; Bhattacharyya, R.; McDonald, A. Impact of conservation tillage in rice-based cropping systems on soil aggregation, carbon pools and nutrients. Geoderma 2019, 340, 104-114. [CrossRef] [PubMed]

65. Kamboj, B.R.; Kumar, A.; Bishnoi, D.K.; Singla, K.; Kumar, V.; Jat, M.L.; Chaudhary, N.; Jat, H.S.; Gosain, D.K.; Khippal, A.; et al. Direct Seeded Rice Technology in Western Indo-Gangetic Plains of India: CSISA Experiences; CSISA, IRRI and CIMMYT: Patna, India, 2012; pp. 1-16.

66. Choudhary, K.M.; Jat, H.S.; Nandal, D.P.; Bishnoi, D.K.; Sutaliya, J.M.; Choudhary, M.; Sharma, P.C.; Jat, M.L. Evaluating alternatives to rice-wheat system in western Indo-Gangetic Plains: Crop yields, water productivity and economic profitability. Field Crop. Res. 2018, 218, 1-10. [CrossRef]

67. Gathala, M.K.; Kumar, V.; Sharma, P.C.; Saharawat, Y.S.; Jat, H.S.; Singh, M.; Kumar, A.; Jat, M.L.; Humphreys, E.; Sharma, D.K.; et al. Optimizing intensive cereal-based cropping systems addressing current and future drivers of agricultural change in the northwestern Indo-Gangetic Plains of India. Agric. Ecosyst. Environ. 2013, 177, 85-97. [CrossRef]

68. Jat, M.L.; Gathala, M.K.; Saharawat, Y.S.; Ladha, J.K.; Singh, Y. Conservation agriculture in intensive rice-wheat rotation of western Indo-Gangetic Plains: Effect on crop physiology, yield, water productivity and economic profitability. Int. J. Environ. Sci. Nat. Resour. 2019, 18, 555988.

69. Jat, M.L.; Gathala, M.K.; Ladha, J.K.; Saharawat, Y.S.; Jat, A.S.; Kumar, V.; Sharma, S.K.; Kumar, V.; Gupta, R. Evaluation of precision land leveling and double zero-till systems in the rice-wheat rotation: Water use, productivity, profitability and soil physical properties. Soil Tillage Res. 2009, 105, 112-121. [CrossRef]

70. Kumar, V.; Ladha, J.K. Direct seeding of rice: Recent developments and future research needs. Adv. Agron. 2011, 111, $297-413$.

71. Hobbs, P.R.; Singh, Y.; Giri, G.S.; Lauren, J.G.; Duxbury, J.M. Direct Seeding and Reduced Tillage Options in the Rice-Wheat Systems of the Indo-Gangetic Plains of South Asia; Pandey, S., Mortimer, M., Wade, L., Tuong, T.P., Lopez, K., Hardy, B., Eds.; IRRI: Los Baños, PH, USA, 2002; pp. 201-215. 
72. Sapkota, T.B.; Jat, M.L.; Aryal, J.P.; Jat, R.K.; Khatri-Chhetri, A. Climate change adaptation, greenhouse gas mitigation and economic profitability of conservation agriculture: Some examples from cereal systems of Indo-Gangetic Plains. J. Integr. Agric. 2015, 22, 1917. [CrossRef]

73. Nawaz, A.; Farooq, M.; Lal, R.; Rehman, A. Comparison of conventional and conservation rice-wheat systems in Punjab, Pakistan. Soil Tillage Res. 2017, 169, 35-43. [CrossRef]

74. Tuong, T.P.; Singh, A.K.; Siopongco, J.D.; Wade, L.J. Constraints to high yield of dry-seeded rice in the rainy season of a humid tropic environment. Plant Prod. Sci. 2000, 3, 164-172. [CrossRef]

75. Baghel, J.K.; Das, T.K.; Mukherjee, I.; Nath, C.P.; Bhattacharyya, R.; Ghosh, S.; Raj, R. Impacts of conservation agriculture and herbicides on weeds, nematodes, herbicide residue and productivity in direct-seeded rice. Soil Tillage Res. 2020, $201,104634$. [CrossRef]

76. Erenstein, O.; Laxmi, V. Zero tillage impacts in India's rice-wheat systems: A review. Soil Tillage Res. 2008, 100, 1-4. [CrossRef]

77. Singh, G.; Kumar, D.; Sharma, P. Effect of organics, biofertilizers and crop residue application on soil microbial activity in rice-wheat and rice-wheat mungbean cropping systems in the Indo-Gangetic plains. Cogent Geosci. 2015, 1, 1085296. [CrossRef]

78. Salahin, N.; Alam, K.; Mondol, A.T.; Islam, M.S.; Rashid, M.H.; Hoque, M.A. Effect of tillage and residue retention on soil properties and crop yields in Wheat-Mungbean-Rice Crop rotation under subtropical humid climate. Open J. Soil Sci. $2017,7,1$. [CrossRef]

79. Bazaya, B.R.; Sen, A.; Srivastava, V.K. Planting methods and nitrogen effects on crop yield and soil quality under direct seeded rice in the Indo-Gangetic plains of eastern India. Soil Tillage Res. 2009, 105, 27-32. [CrossRef]

80. Bhattacharyya, R.; Das, T.K.; Das, S.; Dey, A.; Patra, A.K.; Agnihotri, R.; Ghosh, A.; Sharma, A.R. Four years of conservation agriculture affects topsoil aggregate associated 15nitrogen but not the 15nitrogen use efficiency by wheat in a semi-arid climate. Geoderma 2019, 337, 333-340. [CrossRef]

81. Dixit, J.; Gupta, R.S.R.; Behl, V.P.; Yadav, L.R. No-tillage and conventional tillage system evaluation for production of wheat-an analysis. Indian J. Agric. Res. 2003, 37, 199-203.

82. Singh, A.; Kaur, J. Impact of conservation tillage on soil properties in rice-wheat cropping system. Agric. Sci. Res. J. 2012, 2, 30-41.

83. Ghosh, P.K.; Das, A.; Saha, R.; Kharkrang, E.; Tripathy, A.K.; Munda, G.C.; Ngachan, S.V. Conservation agriculture towards achieving food security in north east India. Curr. Sci. 2010, 99, 915-921.

84. Das, T.K.; Bhattacharyya, R.; Sharma, A.R.; Das, S.; Saad, A.A.; Pathak, H. Impacts of conservation agriculture on total soil organic carbon retention potential under an irrigated agro-ecosystem of the western IndoGangetic Plains. Eur. J. Agron. 2013, 51, 34-42. [CrossRef]

85. Tomar, R.K.; Singh, D.; Gangwar, K.S.; Garg, R.N.; Chakraborty, G.V.K.; Sahoo, D.; Rajeev, R.N.R.; Chakravarty, N.V.K. Effect of tillage systems and irrigation schedules on soil cracking pattern, water requirement and performance of rice-wheat cropping system in inceptisols in semi-arid regions. J. Soil. Water Conserv. 2009, 8, 26-33.

86. Bandyopadhyay, K.K.; Mohanty, M.; Painuli, D.K.; Misra, A.K.; Hati, K.M.; Mandal, K.G.; Ghosh, P.K.; Chaudhary, R.S.; Acharya, C.L. Influence of tillage practices and nutrient management on crack parameters in a Vertisol of central India. Soil Tillage Res. 2003, 71, 133-142. [CrossRef]

87. Alam, M.K.; Salahin, N.; Islam, S.; Begum, R.A.; Hasanuzzaman, M.; Islam, M.S.; Rahman, M.M. Patterns of change in soil organic matter, physical properties and crop productivity under tillage practices and cropping systems in Bangladesh. J. Agric. Sci. 2017, 155, 216-238. [CrossRef]

88. Hati, K.M.; Chaudhary, R.S.; Mohanty, M.; Biswas, A.K.; Bandyopadhyay, K.K. Short-term tillage and fertilization impacts on soil organic carbon, aggregate stability and yield of soybean-wheat system in deep black soils of central India. J. Indian Soc. Soil Sci. 2015, 63, 1-12.

89. Samal, S.K.; Rao, K.K.; Poonia, S.P.; Kumar, R.; Mishra, J.S.; Prakash, V.; Mondal, S.; Dwivedi, S.K.; Bhatt, B.P.; Naik, S.K.; et al. Evaluation of long-term conservation agriculture and crop intensification in rice-wheat rotation of Indo-Gangetic Plains of South Asia: Carbon dynamics and productivity. Eur. J. Agron. 2017, 90, 198-208. [CrossRef] [PubMed]

90. Sapkota, T.B.; Jat, R.K.; Singh, R.G.; Jat, M.L.; Stirling, C.M.; Jat, M.K.; Bijarniya, D.; Kumar, M.; Yadvinder-Singh; Saharawat, Y.; et al. Soil organic carbon changes after seven years of conservation agriculture in a rice-wheat system of the eastern IndoGangetic Plains. Soil Use Manag. 2017, 33, 81-89. [CrossRef]

91. Singh, G.; Bhattacharyya, R.; Das, T.K.; Sharma, A.R.; Ghosh, A.; Das, S.; Jha, P. Crop rotation and residue management effects on soil enzyme activities, glomalin and aggregate stability under zero tillage in the Indo-Gangetic Plains. Soil Tillage Res. 2018, 184, 291-300. [CrossRef]

92. Dey, A.; Dwivedi, B.S.; Bhattacharyya, R.; Datta, S.P.; Meena, M.C.; Das, T.K.; Singh, V.K. Conservation agriculture in a rice-wheat cropping system on an alluvial soil of north-western Indo-Gangetic plains: Effect on soil carbon and nitrogen pools. J. Indian Soc. Soil Sci. 2016, 64, 246-254. [CrossRef]

93. Bhattacharyya, R.; Prakash, V.; Kundu, S.; Gupta, H.S. Effect of tillage and crop rotations on pore size distribution and soil hydraulic conductivity in sandy clay loam soil of the Indian Himalayas. Soil Tillage Res. 2006, 86, 129-140. [CrossRef]

94. Kumar, N.; Nath, C.P.; Hazra, K.K.; Das, K.; Venkatesh, M.S.; Singh, M.K.; Singh, S.S.; Praharaj, C.S.; Singh, N.P. Impact of zero-till residue management and crop diversification with legumes on soil aggregation and carbon sequestration. Soil Tillage Res. 2019, 189, 158-167. [CrossRef] 
95. Mishra, G.; Kushwaha, H.S. Winter wheat yield and soil physical properties responses to different tillage and irrigation. Eur. J. Biol. Res. 2016, 6, 56-63.

96. Hati, K.M.; Chaudhary, R.S.; Mandal, K.G.; Bandyopadhyay, K.K.; Singh, R.K.; Sinha, N.K.; Mohanty, M.; Somasundaram, J.; Saha, R. Effects of tillage, residue and fertilizer nitrogen on crop yields, and soil physical properties under soybean-wheat rotation in vertisols of Central India. Agric. Res. 2015, 4, 48-56. [CrossRef]

97. Kumari, M.; Chakraborty, D.; Gathala, M.K.; Pathak, H.; Dwivedi, B.S.; Tomar, R.K.; Garg, R.N.; Singh, R.; Ladha, J.K. Soil aggregation and associated organic carbon fractions as affected by tillage in a rice-wheat rotation in North India. Soil Sci. Soc. Am. J. 2011, 75, 560-567. [CrossRef]

98. Bhattacharyya, P.; Roy, K.S.; Neogi, S.; Adhya, T.K.; Rao, K.S.; Manna, M.C. Effects of rice straw and nitrogen fertilization on greenhouse gas emissions and carbon storage in tropical flooded soil planted with rice. Soil Tillage Res. 2012, 124, 119-130. [CrossRef]

99. Talukder, H.; Meisner, C.A.; Baksh, M.E.; Waddington, S.R. Wheat-maize-rice cropping on permanent raised beds in Bangladesh. Permanent beds and rice-residue management for rice-wheat systems in the Indo-Gangetic Plain. In Proceedings of the Workshop, Ludhiana, India, 7-9 September 2006; pp. 111-123.

100. Mondal, S.; Kumar, S.; Haris, A.A.; Dwivedi, S.K.; Bhatt, B.P.; Mishra, J.S. Effect of different rice establishment methods on soil physical properties in drought-prone, rainfed lowlands of Bihar. India. Soil Res. 2016, 54, 997-1006. [CrossRef]

101. Sharma, P.C.; Jat, H.S.; Kumar, V.; Gathala, M.K.; Datta, A.; Yaduvanshi, N.P.S.; Choudhary, M.; Sharma, S.; Singh, L.K.; Saharawat, Y.; et al. Sustainable Intensification Opportunities under Current and Future Cereal Systems of North-West India; Central Soil Salinity Research Institute: Karnal, India, 2015; p. 46.

102. Alam, M.K.; Bell, R.W.; Haque, M.E.; Kader, M.A. Minimal soil disturbance and increased residue retention increase soil carbon in rice-based cropping systems on the Eastern Gangetic Plain. Soil Tillage Res. 2018, 183, 28-41. [CrossRef]

103. Gathala, M.K.; Ladha, J.K.; Saharawat, Y.S.; Kumar, V.; Kumar, V.; Sharma, P.K. Effect of tillage and crop establishment methods on physical properties of a medium-textured soil under a seven-year rice-wheat rotation. Soil Sci. Soc. Am. J. 2011, 75, 1851-1862. [CrossRef]

104. Shahzad, M.; Hussain, M.; Farooq, M.; Farooq, S.; Jabran, K.; Nawaz, A. Economic assessment of conventional and conservation tillage practices in different wheat-based cropping systems of Punjab, Pakistan. Environ. Sci. Pollut. Res. 2017, 24, 24634-24643. [CrossRef] [PubMed]

105. Lupwayi, N.Z.; Hanson, K.G.; Harker, K.N.; Clayton, G.W.; Blackshaw, R.E.; O’Donovan, J.T.; Johnson, E.N.; Gan, Y.; Irvine, R.B.; Monreal, M.A. Soil microbial biomass, functional diversity and enzyme activity in glyphosate-resistant wheat-canola rotations under low-disturbance direct seeding and conventional tillage. Soil Biol. Biochem. 2007, 39, 1418-1427. [CrossRef]

106. Sharma, P.; Singh, G.; Singh, R.P. Conservation tillage, optimal water and organic nutrient supply enhance soil microbial activities during wheat (Triticum aestivum L.) cultivation. Braz. J. Microbiol. 2011, 42, 531-542. [CrossRef]

107. Shaver, T.M.; Peterson, G.A.; Ahuja, L.R.; Westfall, D.G.; Sherrod, L.A.; Dunn, G. Surface soil physical properties after twelve years of dryland no-till management. Soil Sci. Soc. Am. J. 2002, 66, 1296-1303. [CrossRef]

108. Saunders, C.; Davis, L.; Pearce, D. Rice-Wheat Cropping Systems in India and Australia, and Development of the Happy Seeder; ACIAR Impact Assessment Series Report No.77; Australian Centre for International Agricultural Research: Canberra, Australia, 2012.

109. Jat, H.S.; Jat, R.K.; Singh, Y.; Parihar, C.M.; Jat, S.L.; Tetarwal, J.P.; Sidhu, H.S.; Jat, M.L. Nitrogen management under conservation agriculture in cereal-based systems. Ind. J. Fert. 2016, 12, 76-91.

110. Singh, A.P.; Sakal, R.; Sinha, R.B.; Bhogal, N.S. Use efficiency of applied zinc alone and mixed with biogas slurry in rice-wheat cropping system. J. Ind. Soc. Soil Sci. 1998, 46, 75-80.

111. Parihar, C.M.; Singh, A.K.; Jat, S.L.; Dey, A.; Nayak, H.S.; Mandal, B.N.; Saharawat, Y.S.; Jat, M.L.; Yadav, O.P. Soil quality and carbon sequestration under conservation agriculture with balanced nutrition in intensive cereal-based system. Soil Tillage Res. 2020, 202, 104653. [CrossRef]

112. Mahajan, A.; Gupta, R.D. Integrated nutrient management (INM) in a sustainable rice wheat cropping system. In The Rice-Wheat Cropping System; Mahajan, A., Gupta, R.D., Eds.; Springer: Dordrecht, The Netherlands, 2009; pp. $109-117$.

113. Farooq, M.; Ullah, A.; Rehman, A.; Nawaz, A.; Nadeem, A.; Wakeel, A.; Nadeem, F.; Siddique, K.H. Application of zinc improves the productivity and biofortification of fine grain aromatic rice grown in dry seeded and puddled transplanted production systems. Field Crops Res. 2018, 216, 53-62. [CrossRef]

114. Atique-ur-Rehman, A.; Farooq, M.; Nawaz, A.; Ahmad, R. Influence of boron nutrition on the rice productivity, kernel quality and biofortification in different production systems. Field Crop. Res. 2014, 169, 123-131. [CrossRef]

115. Atique-ur-Rehman; Farooq, M.; Rashid, A.; Nadeem, F.; Stuerz, S.; Asch, F.; Bell, R.W. Boron nutrition of rice in different production systems. A review. Agron. Sustain. Dev. 2018, 38, 25. [CrossRef]

116. Kumar, S.; Karaliya, S.K.; Chaudhary, S. Precision farming technologies towards enhancing productivity and sustainability of rice-wheat cropping system. Int. J. Curr. Microbio. App. Sci. 2017, 6, 142-151. [CrossRef]

117. Singh, R.K.; Bohra, J.S.; Nath, T.; Singh, Y.; Singh, K. Integrated assessment of diversification of rice-wheat cropping system in Indo-Gangetic plain. Arch. Agron. Soil Sci. 2011, 57, 489-506. [CrossRef]

118. Yaqub, M.; Mahmood, T.; Akhtar, M.; Iqbal, M.M.; Ali, S. Induction of mungbean (Vigna radiata (L.) wilczek) as a grain legume in the annual rice-wheat double cropping system. Pak. J. Bot. 2010, 42, 3125-3135. 
119. Kumar, R.; Mishra, J.S.; Rao, K.K.; Mondal, S.; Hazra, K.K.; Choudhary, J.S.; Hans, H.; Bhatt, B.P. Crop rotation and tillage management options for sustainable intensification of rice-fallow agro-ecosystem in eastern India. Sci. Rep. 2020, 10, 1-5. [CrossRef]

120. Wani, S.P.; Rupela, O.P.; Lee, K.K. Sustainable agriculture in the semi-arid tropics through biological nitrogen fixation in grain legumes. Plant Soil 1995, 174, 29-49. [CrossRef]

121. Giller, K.E. Nitrogen Fixation in Tropical Cropping Systems; CAB Int.: Wallingford, UK, 2001; p. 423.

122. Shah, Z.; Ahmad, S.R.; Rahman, H.U. Sustaining rice-wheat system through management of legumes I: Effect of green manure legumes on rice yield and soil quality. Pak. J. Bot. 2011, 43, 1569-1574.

123. Quick, G.R.; Quick, G.R. The Rice Harvesters Reference. Rural Industries Research and Development Corporation, 1999. RIRDC Rice Research and Development Program. RIRDC Publication No. 99/38. Available online: https://static1.squarespace.com/ static/5a03c05bd0e62846bc9c79fc/t/5a4afdbfc83025f844b718de/1514864080791/99-046.pdf (accessed on 31 December 2020).

124. Hasan, K.; Tanaka, T.S.; Alam, M.; Ali, R.; Saha, C.K. Impact of Modern Rice Harvesting Practices over Traditional Ones. Rev. Agric. Sci. 2020, 8, 89-108. [CrossRef]

125. Hasan, M.K.; Ali, M.R.; Saha, C.K.; Alam, M.M.; Hossain, M.M. Assessment of paddy harvesting practices of Southern Delta Region in Bangladesh. Progress. Agric. 2019, 30, 57-64. [CrossRef]

126. Jones, M.; Alam, M.M.; Rahman, M.H.; Ali, M.R.; Hasan, M.K.; Pathan, M.S.I.A. Gender Technology Assessment of Harvesting Technologies in Bangladesh. Agrilinks, the Online Hub, Is a Part of the U.S. Government's Feed the Future. Available online: https:/ / www.agrilinks.org/sites / default/files/resources/bangladesh_harvester_tech_profile_2019_08 (accessed on 31 December 2020).

127. Tiwari, P.S.; Gurung, T.R.; Sahni, R.K.; Kumar, V. Agricultural Mechanization Trends in SAARC Region; Gurung, T.R., Kabir, W., Bokhtiar, S.M., Eds.; Mechanization for Sustainable Agricultural Intensification in SAARC Agriculture Centre: Dhaka, Bangladesh, 2017; p. 302.

128. Ali, M.R.; Hasan, M.K.; Saha, C.K.; Alam, M.M.; Hossain, M.M.; Kalita, P.K.; Hansen, A.C. Role of mechanical rice harvesting in socio-economic development of Bangladesh. In Proceedings of the An ASABE Meeting Presentation, Detroit, MI, USA, 29 July-1 August 2018. Paper Number: 1800751.

129. Praweenwongwuthi, S.; Laohasiriwong, S.; Rambo, A.T. Impacts of rice combine harvesters on economic and social of farmers in a village of the Tung Kula Ronghai Region. Res. J. Agri. Biol. Sci. 2010, 6, 778-784.

130. Kurhekar, S.P.; Patil, S.R. Performance evaluation of self-propelled walking type vertical conveyor reaper. Int. J. Process. Post Harvest Technol. 2011, 2, 29-31.

131. Veerangouda, M.; Sushilendra, S.; Prakash, K.V.; Anantachar, M. Performance evaluation of tractor operated combine harvester. Kamataka J. Agric. Sci. 2010, 23, 282-285.

132. Ramesh, T.; Rathika, S. Evaluation of rice cultivation systems for greenhouse gases emission and productivity. Int. J. Ecol. Environ. Sci. 2020, 2, 49-54.

133. Islamic Republic of Pakistan; Asian Development Bank. Final Report, TA 8578-PAK: Punjab Basmati Rice Value Chain; Islamic Republic of Pakistan: Islamabad, Pakistan; Asian Development Bank: Metro Manila, Philippines, 2018. 